\title{
Viral reinfection affecting bulb production in garlic after seven years of cultivation under field conditions
}

\author{
Péricles de Albuquerque Melo Filho ${ }^{1}$, Renato Oliveira Resende ${ }^{2}$, Célia Maria Torres Cordeiro ${ }^{3}$, \\ José Amauri Buso ${ }^{4}$, Antonio Carlos Torres ${ }^{4}$, and André Nepomuceno Dusi ${ }^{4, *}$ \\ ${ }^{1}$ Departamento de Agronomia, Universidade Federal Rural de Pernambuco, CEP 52.171-900, Recife, PE, Brasil; \\ ${ }^{2}$ Departamento de Biologia Celular, Universidade de Brasília, CEP 70919-900, Brasília, DF, Brasil; \\ ${ }^{3}$ Embrapa Recursos Genéticos e Biotecnologia, Caixa Postal 02372, Brasília, DF, 70770-900, Brasil; \\ ${ }^{4}$ Embrapa Hortaliças, Caixa Postal 218, CEP 70359-970, Brasilia, DF, Brasil; * Author for Correspondence \\ (E-mail:dusi@cnph.embrapa.br)
}

Accepted 30 June 2006

Key words: epidemiology, garlic-seed, potyvirus, spatial-spread, temporal-spread, virus-free plants

\begin{abstract}
Six sequential field experiments were conducted from 1999 to 2002 to evaluate virus reinfection in garlic cv. Amarante and its effect on bulb production. The treatments in the year 1999 were: $T_{1}$ - virus-free garlicseed obtained by thermotherapy and meristem-tip culture and indexed for virus by immuno-sorbent electron microscopy (ISEM) under its first field cycle; $\mathrm{T}_{2}, \mathrm{~T}_{3}$ and $\mathrm{T}_{4}$ - garlic-seed in the second, third and fourth field cycles, respectively; and $\mathrm{C}$ - standard garlic-seed from the grower (with no control of virus infection) as a control. In the years 2000 to 2002, a new plot of virus-free seed was added to the experiment and cloves from the previous treatments were again grown under field conditions. In the fourth year of experiments, the treatments comprised $\mathrm{T}_{1}$ (virus-free garlic seeds under the first field cycle) to $\mathrm{T}_{7}$ (garlicseed in the sixth field cycle) and C. Two experiments were conducted in the years 1999 and 2000, at two locations and in the years 2001 and 2002 only one experiment per year at one location. The combined analysis of variance for all experiments indicated a significant difference between the treatments for plant height and yield. The bulbs were classified into commercial classes according the Brazilian regulation and the commercial classes $4-7$ were $72 \%, 60 \%, 59 \%, 53 \%$ and $35 \%$ of the total number of bulbs harvested, from $\mathrm{T}_{1}$ to $\mathrm{T}_{5}$, respectively. Virus reinfection at the end of the second field cycle, determined by serology using antisera against the most common viruses of garlic in Brazil reached $83 \%$. Treatments $\mathrm{T}_{1}-\mathrm{T}_{7}$ yielded $118 \%, 79 \%, 57 \%, 51 \%, 39 \%, 33 \%$ and $31 \%$ higher than the control.
\end{abstract}

\section{Introduction}

The garlic crop, which is exclusively vegetatively propagated, can be infected with several virus species. The most common viruses infecting garlic in South America are Onion yellow dwarf virus (OYDV), Leek yellow stripe virus (LYSV), Garlic common latent virus (GCLV), and at least three Allexivirus species (Conci et al., 1999; Melo Filho et al., 2004). The above species are also important world-wide together with other species such as Shallot latent virus (SLV) and other allexiviruses. With the development of the thermotherapy and meristem tip culture techniques for cleaning plants of virus (Robert et al., 1998; Conci et al., 2000; Torres et al., 2000), it is now possible to design experiments to evaluate the damage caused by virus reinfection. Field studies in Brazil starting 
with virus-free seed of $\mathrm{cv}$. Amarante indicated that, at the end of the third year, $47 \%$ of the plants were infected with viruses and had a yield $27 \%$ lower than the plants of the first year (Tanabe, 1999). The same study indicated that cleaning garlic plants from viruses can increase yield by more than $100 \%$ when compared to the standard garlic seed used by farmers (Fajardo, 1998; Tanabe, 1999). Similar results were obtained in Argentina, where $42-100 \%$ was reinfected by the end of the first year (Conci et al., 2003). The bulb weight was an average of $75.7 \mathrm{~g}$ in the first crop cycle compared to $33.4 \mathrm{~g}$ in the virus-infected control plants, representing a gain in weight of about $125 \%$. Considering that the yield of virusfree plants may represent the full potential for the crop, it is clear that with an increasing number of crop cycles, viral re-infection progressively reduces the yield of the bulb weight of the plants of the second and third field cycles; the standard seed yields were $11 \%$ and $44 \%$ lower than the first field field cycle plots, respectively. The yield reduction in the subsequent years was even higher.

Usually, in Brazil, the growers use part of their crop as seed for the next year (Nakamae and Pastrello, 2002). As the seed market is not regulated, this practice enhances the dissemination of viruses and other diseases across the country. Seeds originating from virus-free stock are not yet commercially available and the establishment of a seed programme requires substantial investment. The possibility of several field multiplications under controlled conditions, such as isolated fields with a low inoculum pressure, might help to decrease the cost of the seed with a high sanitary status.

Based on the demand for higher quality seed stock, the aim of this work was to evaluate the number of multiplications that virus-free garlic seed could undergo still allowing for a profitable cost/benefit ratio. The data from the experiments will help in the design of a high quality seed production system and increased yields.

\section{Materials and methods}

\section{Experimental design of the reinfection assays}

Six field experiments were conducted with cv. Amarante to evaluate viral reinfection rates. The treatments in the year 1999 were $T_{1}$ (the first field field cycle of virus-free garlic seed previously obtained by thermotherapy and meristem tip culture and indexed for virus by immuno-sorbent electron microscopy (ISEM) using a polyclonal polyvalent antiserum produced at Embrapa Hortaliças); $\mathrm{T}_{2}, \mathrm{~T}_{3}$ and $\mathrm{T}_{4}$ - garlic seed in the second, third and fourth field cycles - produced in previous experiments by Fajardo (1998) and Tanabe (1999) at Embrapa Hortaliças experimental fields; $\mathrm{C}$ - as a control, standard garlic seed from the grower with no control of virus infections. The rabbit polyclonal antiserum used was produced by injecting a virus mix purified from field-infected plants. This antiserum detects the garlic viruses belonging to the Allexivirus, Carlavirus and Potyvirus genera (Tanabe, 1999). In 2000, 2001 and 2002, a new plot of virus-free seed was added to the experiment and the previous treatments were again grown under field conditions. In the fourth year of experiments, the treatments ranged from $\mathrm{T}_{1}$ to $\mathrm{T}_{7}$, plus the control. The control plot was always the standard seed used by growers, which are naturally infected with several poty, carla and allexiviruses. The virus-free cloves were continuously multiplied under an aphid-proof screenhouse to provide material for $\mathrm{T}_{1}$ in all years. Two experiments were conducted in the years 1999 and 2000, at two distinct locations (Gama, DF; Água Fria, GO - Brazil) and in the years 2001 and 2002 with one experiment per year at Gama, DF. All experiments were planted in April and harvested in August, which is the most favourable period for the crop. Each experiment was a randomised complete block design with six replications. The plots had $2.0 \times 1.0 \mathrm{~m}$ with 30 cloves $\mathrm{m}^{-2}$. The crop was grown according the standard agronomic practices used by the growers in the central-west and north-east of Brazil (Menezes Sobrinho, 1997). In 2002, the experiment had a total of eight treatments, from virus-free to six field cycles, plus the standard seed control plot.

Aphid occurrence during the crop cycle in 1999 in both locations and 2000 in Gama was monitored through the capture of alatae morphs by one yellow tray water trap, to demonstrate the incidence of aphids during the experiment. The trap was placed at one border of the experimental plot $7 \mathrm{~cm}$ above ground. Captured aphids were collected every three days after the experiment was established. First collection in Água Fria (1999) 
was on May 22nd; in Gama the first collections were on April 20th and April 25th for 1999 and 2000, respectively. The collected specimens were identified for genus and total number of individuals were plotted against collection date.

\section{Evaluation procedure}

Fifteen plants per plot were evaluated for plant height in 1999 and number of leaves at 60 (in 1999) and 90 days (in all years) after planting (DAP). The other evaluated characteristics were total bulb weight 30 days after harvest (DAH) and stored in a shaded and naturally ventilated barn; average weight and number of bulbs of commercial classes were separated by mechanical classification based on the diameter as defined by Brazilian regulations. The classes are: class $1-<27 \mathrm{~mm}$; class $2-$ 27-32 mm; class 3 - 33-37 mm; class $4-38-$ $42 \mathrm{~mm}$; class 5 - 43-47 mm; class 6-48-56 mm; class $7->56 \mathrm{~mm}$. Only classes $4-7$ are considered commercial classes and were then used for the analysis. Bulbs of classes 1-3 were discarded.

\section{Reinfection rate}

Virus infection average after harvest was determined by testing 5 bulbs/plot at the end of the 2002 experiment. One clove from each bulb, after breaking of dormancy, was planted in a plastic tray under greenhouse conditions. Thirty DAP, the apical leaf was collected and tested by dotElisa (ELISA on nitrocelullose membrane Jayasinghe and Salazar, 1993) using a polyvalentpolyclonal antiserum and a specific polyclonal antiserum against OYDV produced at Embrapa Vegetables and a specific polyclonal antiserum against LYSV kindly provided by Dr. Vilma Conci (IFFIVE/INTA, Argentina).

\section{Statistical analysis}

The number of leaves and plant height in 1999 was analysed according to a randomised complete block design with a split-plot arrangement, grouping the two experiments. Main plots were treatments $\left(\mathrm{T}_{1}-\mathrm{T}_{4}\right.$, control) and sub-plots were evaluation date (60 and 90 DAP). The data were analysed statistically by the GLM procedure of the Statistical Analysis System - SAS (SAS Institute Inc., 1999). This analysis was made only for the two experiments conducted in 1999 to determine the need to collect data of both 60 and 90 DAP for the next experiments. As no effect of date of evaluation was observed, only data for plant height at 90 DAP were collected in the following experiments.

A combined analysis considered data of the six experiments in the 4 years together. The statistical model considered the effects of the two locations (environment), block within environment, treatment and the interaction treatment vs. environment. Each combination of location and year was considered a different environment. Treatment effect was considered fixed and the others were considered random. Treatment effect was decomposed comparing each treatment with the control plot (standard growers seed) using the Dunnett bilateral test at $1 \%$ of probability. These comparisons used the least squares means predicted from the adjusted model. Variance analysis and further comparisons used the Mixed procedure of SAS (SAS Institute Inc., 1999). A correlation analysis was performed between plant height and yield.

An exponential decay model was fitted to the average yield data obtained for each number of field cycles. The model used was:

$$
\hat{y}=a \cdot \exp (-b \cdot x)+c
$$

where $a$ is the amplitude; $b$ is the rate constant, $c$ is yield of the control plot (which is the baseline for the comparisons); $x$ is the number of field field cycle; $\hat{y}$ is the expected yield.

\section{Spatial spread of viruses}

Two experiments were conduced in 2001 and 2002; the experimental design is illustrated in Figure 1. Each experiment was established $1,000 \mathrm{~m}$ away from any Alliaceae plant. The aim of the assay was to verify the distance of spread from the inoculum source, the potential effect of wind direction and the viral species prevalence. One circular plot of $5 \mathrm{~m}$ diam (ca. $19.6 \mathrm{~m}^{2}$ ) was planted with virusinfected cloves of garlic cv. Amarante. The infection was confirmed by dot-ELISA using the polyvalent-polyclonal antiserum. This inoculum source was surrounded by $2 \mathrm{~m}^{2}$ parcels $(2.0 \times 1.0 \mathrm{~m})$ of virus-free garlic plants, 50 plants $\mathrm{m}^{-2}$, radially distributed in eight directions $(\mathrm{N}$, NE, E, SE, S, SW, W and NW). The parcels were 


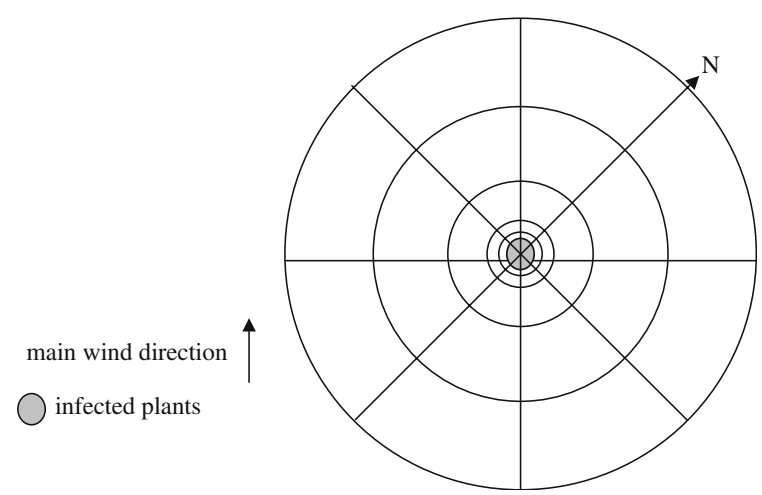

Figure 1. Scheme of the spatial spread field trials.

$3.5 ; 5.5 ; 8.5 ; 18.5$ and $30.0 \mathrm{~m}$ from the viruses source. No insecticide was used in the experiments and the area that was not planted with garlic was kept in bare soil to improve aphid attraction (Liewehr and Cranshaw, 1991). The experiments were harvested around 150 DAP. Twenty bulbs/ parcel were collected. After a natural break of dormancy, one clove of each bulb was planted and then indexed for virus by dot-ELISA using the specific antisera for OYDV and LYSV and the polyvalent-polyclonal antiserum against the viral complex.

\section{Results}

Aphids of the genus Aphis spp., Geopenphigus spp., Hyperomyzus spp., Lipaphis spp., Myzus persicae, Neotoxoptera formosana and Rhopalosiphum spp.

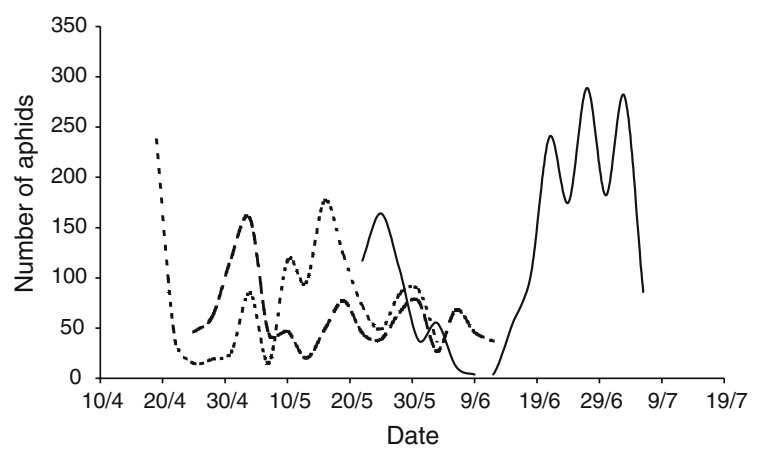

Figure 2. Alatae aphid population collected by the yellow water pan trap in 1999 at Água Fria (-) and Gama (--) and in 2000 at Gama (.....).

were the most common specimens. Total aphid population for each year is shown in Figure 2.

For plant height, in both locations, an effect for treatment and evaluation period was observed, but not for their interaction $(P=0.83$ and $P=0.4)$. This allowed the evaluation to be made only 90 DAP in the subsequent experiments. From the first to the sixth generation yield was progressively reduced; the correlation coefficient between these variables was $r=0.96$; $P<0.001$. The bulb weight was also significantly affected by successive crop cultivation (Table 1). The combined analysis of variance for all six experiments indicated that the effect of treatment was significant for plant height and bulb weight in relation to the control. Infection rates observed in the experiment conducted at Gama (DF) in 2002 at the end of the crop cycle are presented in Table 2.

Table 1. Agronomic characteristics of the garlic plants originating from virus-free cloves at several growth cycles

\begin{tabular}{|c|c|c|c|c|c|}
\hline \multirow[t]{2}{*}{ Treatment } & \multicolumn{3}{|c|}{ Least square mean $\left( \pm \mathrm{SEM}^{1}\right)$} & \multirow[t]{2}{*}{ Average number of bulbs ${ }^{3}$} & \multirow[t]{2}{*}{$\mathrm{YIRC}^{4} \%$} \\
\hline & Plant height $(\mathrm{cm})$ & Bulb weight (g) & Yield $\left(\mathrm{t} \mathrm{ha}^{-1}\right)$ & & \\
\hline $\mathrm{T}_{1}$ & $52.19(2.46) * *(2)$ & $17.22(1.84) * *(2)$ & $10.74(1.25)^{* *(2)}$ & 59 & 117.85 \\
\hline $\mathrm{T}_{2}$ & $49.62(2.46) * *$ & $15.94(1.84) * *$ & $8.82(1.25) * *$ & 54 & 78.90 \\
\hline $\mathrm{T}_{3}$ & $47.97(2.46) * *$ & $13.64(1.84) * *$ & $7.71(1.25) * *$ & 53 & 56.39 \\
\hline $\mathrm{T}_{4}$ & $47.15(2.46)^{* *}$ & $13.14(1.84) * *$ & $7.43(1.25) * *$ & 53 & 50.71 \\
\hline $\mathrm{T}_{5}$ & $45.60(2.54)^{\mathrm{NS}}$ & $12.60(1.90)^{\mathrm{NS}}$ & $6.86(1.28)^{\mathrm{NS}}$ & 52 & 39.15 \\
\hline $\mathrm{T}_{6}$ & $43.23(2.75)^{\mathrm{NS}}$ & $12.40(2.07) \mathrm{NS}$ & $6.55(1.37)^{\mathrm{NS}}$ & 48 & 32.86 \\
\hline $\mathrm{T}_{7}$ & $42.58(3.13) \mathrm{NS}$ & $13.23(2.36)^{\mathrm{NS}}$ & $6.48(1.54)^{\mathrm{NS}}$ & 43 & 31.44 \\
\hline Control & $41.24(2.46)$ & $10.03(1.84)$ & $4.93(1.25)$ & 49 & \\
\hline
\end{tabular}

Experiments conducted from 1999 to 2002.

1. Standard error of the mean; 2. Difference in relation to the standard seed control plots, evaluated with the Dunnetts bilateral test at $1 \%$ : ** significant, N.S. not significant ; 3 . Number of bulbs harvested per plot; 4. Yield Increase in Relation to the standard seed Control plots (YIRC). 
Table 2. Virus infection of the experiment in 2002 determined by dot-ELISA

\begin{tabular}{lccc}
\hline Treatment & Polyvalent (\%) & OYDV $(\%)$ & LYSV (\%) \\
\hline $\mathrm{T}_{1}$ & 26.7 & 23.3 & 3.3 \\
$\mathrm{~T}_{2}$ & 83.3 & 80.0 & 26.6 \\
$\mathrm{~T}_{3}$ & 60.0 & 43.3 & 36.7 \\
$\mathrm{~T}_{4}$ & 86.7 & 100.0 & 93.3 \\
$\mathrm{~T}_{5}$ & 100.0 & 100.0 & 80.0 \\
$\mathrm{~T}_{6}$ & 96.7 & 100.0 & 96.7 \\
$\mathrm{~T}_{7}$ & 100.0 & 100.0 & 100.0 \\
$\mathrm{~T}_{8}$ & 100.0 & 100.0 & 100.0 \\
\hline
\end{tabular}

Values correspond to the average of six replications, five plants per replication.

The yield data was fitted to an exponential decay model (Figure 3), which corroborates the statistical analysis output presented in Table 1.

No directional effect was observed in the spatial spread experiment, as there was no prevalence regarding the eight different lines or wind effect. Infection level was higher at the plots closer to the inoculum source and only one infected plant was observed at the last radius in the first year (Table 3).

\section{Discussion}

Non-persistent transmitted viruses, such as the potyviruses, are usually not aphid species-specific (Dusi and Peters, 1999; Sigvald, 1987). Both colonising and non-colonising species may transmit the viruses at variable efficiencies and epidemiological studies of theses viruses can be made based on total aphid population (Di Fonso et al., 1997; Dusi et al., 2000; Madden et al., 1987;
Mora-Aguilera et al., 1996). Therefore, the presence of alatae aphids detected during the experiments (Figure 2) indicates that the ecological conditions were highly favourable for virus spread during the years analysed.

Little variation was expected among the garlic cultivars in leaf number between the treatments (Wang and Huang, 1974). Fajardo (1998) and Tanabe (1999) had already observed that no difference for this characteristic could be observed between plants originating from virus-free and standard seed stocks. Based on the results of the experiments of 1999, considering plants at the first to the fourth field crop cycles, it was concluded that the number of leaves was not a suitable characteristic to detect any effect of viral infection and the data regarding this characteristic was not collected in subsequent years.

Yield of plants decreased with increasing number of crop cycles but with a generally low rate. In the seventh field cycle, even with a severe reduction in plant height compared to the first generation plants, yields were at least $31.44 \%$ higher when compared to chronically infected plants (control) that are regularly used by the growers. Similar results were reported by Conci et al. (2003) in Argentina. Virus-free garlic plants, when planted in the field, were quickly infected by viruses, affecting plant vigour and reducing the yield over successive crop cycles.

The largest reduction was observed from the second to the third field cycle (14\%). When the first generation was compared to the fourth, fifth and sixth generations, reductions were $24 \%, 27 \%$ and $28 \%$ respectively.

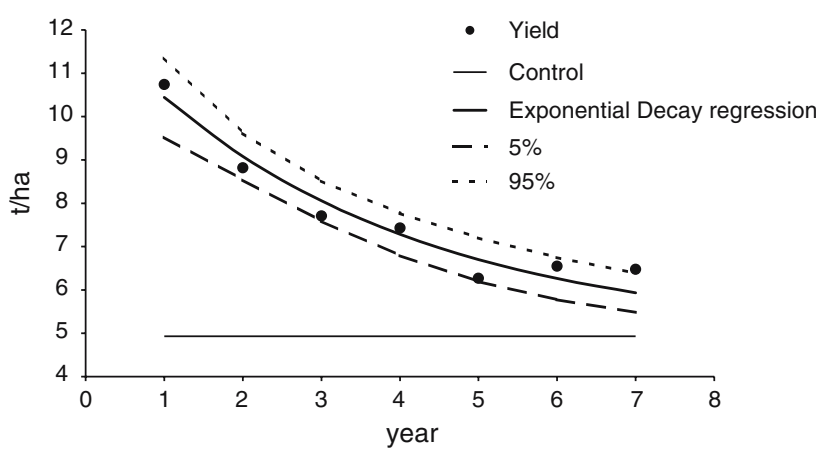

Figure 3. Yield of the garlic plants originating from virus-free cloves at several growth cycles. $(y=7.325 * \exp (-0.284 * x)+4.93$; $\left.r^{2}=0.944 ; P<0.001\right)$. Dashed lines represent the upper and lower borders of a $95 \%$ confidence interval. 
Table 3. Average viral infection in the spatial spread experiment determined by dot-ELISA using a polyvalent-polyclonal antiserum and specific polyclonal antisera against OYDV and LYSV

\begin{tabular}{|c|c|c|c|c|c|c|}
\hline \multirow[t]{2}{*}{ Radio $^{a}$} & \multicolumn{2}{|c|}{ Polyvalent $(\%)$} & \multicolumn{2}{|c|}{ OYDV $(\%)$} & \multicolumn{2}{|c|}{ LYSV (\%) } \\
\hline & 2002 & 2003 & 2002 & 2003 & 2002 & 2003 \\
\hline 1 & 6.3 & 22.5 & 5.0 & 20.8 & 3.8 & 15.0 \\
\hline 2 & 2.5 & 13.8 & 2.5 & 13.8 & 0 & 12.5 \\
\hline 3 & 0 & 6.3 & 0 & 7.5 & 0 & 1.3 \\
\hline 4 & 0 & 3.8 & 0 & 3.8 & 0 & 0 \\
\hline 5 & 0.6 & 0 & 0.6 & 0 & 0.6 & 0 \\
\hline
\end{tabular}

${ }^{\text {a }}$ Parcels of $2 \mathrm{~m}^{2}$ of virus-free garlic plants radially distributed in N, NE, SE, S, SW, W and NW directions. Radio 1-5 were 3.5, 5.5, 8.5, 18.5 and $30 \mathrm{~m}$ from the virus source.

Production of the $T_{1}, T_{2}, T_{3}$ and $T_{4}$ showed a yield of commercial bulbs (classes 4-7) of $71.65 \%$, $60.10 \%, 58.75 \%$ and $52.59 \%$, respectively. Again, Conci et al. (2003) observed similar results after 5 years of successive cultivation. When interpreting their results, it can be concluded that the first field cycle had a yield, on average, $141 \%$ higher than chronically diseased plants, while for the fifth cycle yield was $49 \%$ higher. When considering the perimeter of bulbs, which reflects the commercial class, bulbs produced in the first generation were $33 \%$ larger than virus-infected control plants while in the fifth crop cycle, bulbs were $16 \%$ larger than the chronically diseased plants. Their results showed a gradual loss in yield until the third year, and subsequently the yield values remained steady for the fourth and fifth years of testing but still were higher than those reached by chronically diseased plants.

Even with the high infection rates detected after the first and second field cycles (Table 2), the yield reduction was not observed at the same ratio. Usually, the garlic crop is infected with more than one virus species (Fajardo et al., 2001; van Dijk et al., 1991; van Dijk, 1993) that may interact synergistically to decrease yield. However, it can be observed that although multiple infections of the potyviruses do occur, it is not rare that single infections are detected. This is probably the reason why yield reduction is not directly correlated with reinfection in the first and second crop cycles. With continued use of the same seed, viral titre increases as well as the number of mixed infection plants, which is reflected in a more accentuated decrease in yield.

As a general conclusion, considering that from $\mathrm{T}_{5}$ both yield and number of bulbs in commercial classes (reflected by the average bulb weight) were not significantly different from the control plots (Table 1), it is suggested that the same seed can be used up to four cycles before replacement with a new virus-free seed.

Although the exponential model fitted to the yield data indicates that decay is faster until $\mathrm{T}_{4}$, it is expected that at farm level the use of the same seed can be extended for more years. Yield decay may be influenced by inoculum pressure, environmental conditions, cultivars and virus combination (mixed infection with different virus species) under field conditions. In our work, yield, within commercial classes, significantly decreased with a higher rate until the fifth field cycle and remained almost steady for the fifth to seventh year in open fields (Figure 3). Virus inoculum pressure under experimental conditions is usually higher than under larger cultivated areas. The experiments were conduced in the experimental fields of a research station, amidst a germplasm collection infected with potyviruses, carlaviruses and allexiviruses. As the cultivation scale increases at farm level, using seeds with low infection rates, the inoculum pressure is expected to be lower. Thus, infection rates are also expected to be lower and, consequently, the same seed could be grown for a larger number of field cycles than estimated in our model. This consideration is supported by the fact that, under experimental conditions with high inoculum pressure, $\mathrm{T}_{7}$ yielded $31.44 \%$ higher than the control with $47.68 \%$ of the bulbs in the commercial classes 4-7.

The absence of directional effect on the spatial spread of the non-persistent transmitted potyviruses observed are corroborated by the studies of Dusi (1999) and Nemecek (1993) with Beet mosaic 
virus (BtMV) and Potato virus $Y$ (PVY), respectively. In both studies, the spread of the viruses under field conditions was mainly limited around the inoculum source and the reasoning for that is discussed by them.

Considering that significantly higher yields during at least four crop cycles were observed both in Argentina and Brazil with different cultivars, it is expected that similar results would be obtained with other garlic cultivars in Brazil. Different garlic materials are being now submitted to thermotherapy and shoot-tip culture in Brazil in order to provide different cultivars to the different growing areas in the country.

\section{Acknowledgements}

This work was partially funded by $\mathrm{CBAB} / \mathrm{CNPq}$, Brazil. We also tank Dr. David Bertioli from the Universidade Católica de Brasília for the critical review of both English and content of the manuscript.

\section{References}

Conci VC, Canavelli AE, Lunello PA and Cafrune EE (1999) Mosaico del ajo. In: Projecto de Investigaciones en Fitovirologia. Instituto de Fitopatologia y Fisiologia VegetalIFFIVE y Instituto Nacional de Tecnologia AgropecuáriaINTA. Argentina. (p.p.ajo 1-6).

Conci VC, Bracamonte R, Aloche P, Burashi D, Lunello P and Cafrune E (2000) Producción de plantas de ajo libre de los virus transmitidos por pulgones y ácaros. Horticultura Argentina 19: 60 .

Conci VC, Canavelli AE, Lunello P, diRienzo J, Nome SF, Zumelzu G and Italia R (2003) Yield losses associated with virus-infected garlic plants during five successive years. Plant Disease 87: 1411-1415.

DiFonzo CD, Ragsdale DW, Radcliffe EB, Gudmestad NC and Secor GA (1997) Seasonal abundance of aphid vectors of potato virus $Y$ in the Red River valley of Minnesota and North Dakota. Journal of Economic Entomology 90: 824-831.

Dusi AN (1999) Beet mosaic virus: epidemiology and damage, Wageningen Agricultural University, Wageningen.

Dusi AN and Peters D (1999) Beet mosaic virus: its vector and host relationships. Journal of Phytopathology 147: 293 298.

Dusi AN, Peters D and vander Werf W (2000) Measuring and modelling the effects of inoculation date and aphid flights on the secondary spread of Beet mosaic virus in sugar beet. Annals of Applied Biology 136: 131-146.
Fajardo TVM (1998) Estudo de degenerescência por viroses e caracterização molecular do complexo viral da cultura do alho Universidade de Brasília, Brasília.

Fajardo TVM, Nishijima M, Buso JA, Torres AC, deÁvila AC and Resende RO (2001) Garlic viral complex: identification of potyviruses and carlavirus in central Brazil. Fitopatologia Brasileira 26: 619-626.

Jayasinghe U and Salazar LT (1993) Ensayos inmunológicos con conjugados enzimáticos: en mambranas de nitrocelulosa (NCM-ELISA) IN: CIP - Manual de técnicas en virologia. Centro Internacional de la Papa, Lima.

Liewehr DJ and Cranshaw WS (1991) Alate aphid trap capture over different background colors and different background patterns. Southwestern Entomologist 16: 13-18.

Madden LV, Pirone TP and Raccah B (1987) Analysis of spatial patterns of virus-diseased tobacco plants. Phytopathology 77: 1409-1417.

Melo Filho PA, Nagata T, Dusi AN, Buso JA, Torres AC, Eiras M and Resende RO (2004) Detection of three Allexivirus species infecting garlic in Brazil. Pesquisa Agropecuária Brasileira 39: 375-340.

Menezes Sobrinho JA (1997) Cultivo do alho (Allium sativim L.), 3rd edn. Embrapa Hortaliças, Brasília.

Mora-Aguilera G, Nieto-Angel D, Campbell CL, Téliz D and García E (1996) Multivariate comparison of papaya ringspot epidemics. Phytopathology 86: 70-78.

Nakamae IJ and Pastrello CP (2002) Agrianual 2002, Argos Comunicação, São Paulo.

Nemecek T (1993) The Role of Aphid Behavior in the Epidemiology of Potato Virus Y: A Simulation Study, Swiss Federal Institute of Technology Zürich, Obersiggental.

Robert U, Z'el J and Ravnikar M (1998) Thermoterapy in virus elimination from garlic influences on shoot multiplication from meristems and bulb formation in vitro. Scientia Horticulture 73: 193-202.

SAS Institute Inc (1999) SAS/STAT user's guide, version 6, 4th edn. Cary, NC: SAS Institute Inc.

Sigvald R (1987) Aphid migration and the importance of some aphid species as vectors of potato virus $\mathrm{Y}$ (PVYo) in Sweden. Potato Research 30: 267-283.

Tanabe CMN (1999) Avaliação de degenerescência em campo causada por fitoviroses na cultura do alho (Allium sativum L.) Universidade de Brasília, Brasília.

Torres AC, Fajardo TVM, Dusi AN, Resende RO and Buso JA (2000) Shoot tip culture and thermotherapy in recovering virus free plants of garlic. Horticultura Brasileira 18: 192195.

vanDijk P (1993) Survey and characterization of Potyviruses and their strains of Allium species. Netherlands Journal of Plant Pathology 99: 1-48.

vanDijk P, Verbeek M and Bos L (1991) Mite-borne virus isolates from cultivated Allium species, and their classification into two new rymoviruses in the family Potyviridae. Netherlands Journal of Plant Pathology 97: 381-399.

Wang P and Huang L (1974) Studies on the shoot meristem culture of Allium sativum. Journal of the Chinese Society of Horticultural Science 20: 79-87. 